\title{
Review on the Gender Sensitive Women Education- Legal Revolution in Higher Education
}

\author{
Pradeep M. D. ${ }^{1}$ \& Ravindra B. K. ${ }^{2}$ \\ ${ }^{1}$ Research Scholar, Alliance School of Law, Alliance University, Bengaluru \& Assistant \\ Professor, College of Social Sciences and Humanities, Srinivas University, Mangaluru, \\ Karnataka, India \\ ${ }^{2}$ Vice Chancellor \& Research Guide, Alliance University, Bengaluru, Karnataka, India \\ E-mail: mdpradeepnair767@gmail.com
}

Type of the Paper: Research Article.

Type of Review: Peer Reviewed.

Indexed in: OpenAIRE.

DOI: http://dx.doi.org/10.5281/zenodo.821378.

Google Scholar Citation: IJMTS

\section{How to Cite this Paper:}

M. D., Pradeep, B. K., Ravindra. (2017). Review on the Gender Sensitive Women Education-Legal Revolution in Higher Education. International Journal of Management, Technology, and Social Sciences (IJMTS), 2(1), 53-65.

DOI: http://dx.doi.org/10.5281/zenodo.821378.

International Journal of Management, Technology, and Social Sciences (IJMTS)

A Refereed International Journal of Srinivas University, India.

(C) With Authors.

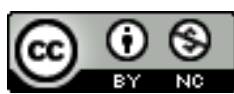

This work is licensed under a Creative Commons Attribution-Non Commercial 4.0 International License subject to proper citation to the publication source of the work.

Disclaimer: The scholarly papers as reviewed and published by the Srinivas Publications (S.P.), India are the views and opinions of their respective authors and are not the views or opinions of the SP. The SP disclaims of any harm or loss caused due to the published content to any party. 


\title{
Review on the Gender Sensitive Women Education- Legal Revolution in Higher Education
}

\author{
Pradeep M. D. ${ }^{1} \&$ Ravindra B. K. ${ }^{2}$ \\ ${ }^{1}$ Research Scholar, Alliance School of Law, Alliance University, Bengaluru \& Assistant \\ Professor, College of Social Sciences and Humanities, Srinivas University, Mangaluru, \\ Karnataka, India \\ ${ }^{2}$ Vice Chancellor \& Research Guide, Alliance University, Bengaluru, Karnataka, India \\ E-mail: mdpradeepnair767@gmail.com
}

\begin{abstract}
Education spreads parallel with the life span of a person starting from his birth to death. Education is known to be the instrument which fills human actions with the essence of values, dignity, ethics and human virtues. Life progress along with the process of civilization equipped with social, moral, cultural attributes in the path of education. The Educational system should be gender sensitive to impart knowledge and disseminate skills to the marginalized sections of the society. The country could excess by facilitating contribution of the marginalized folk in the near future. Autonomous bodies like University Grants Commission (UGC), National Council of Educational Research and Training (NCERT), Central Board of Secondary Education (CBSE) regulates women education system in India. Institutions like United Nation's International Children's Educational Fund (UNICEF), Indian Council of Social Science Research (ICSSR), United Nations Educational Scientific and Cultural Organisation (UNESCO), Council of Scientific and Industrial Research (CSIR), Medical Council of India (MCI) and Dental Council of India (DCI) facilitates women education in India. Women Study Centres aided by UGC study the status, problems, issues concerned with women education. The illiteracy among women makes them dependent and deprived in general. Social, economic and political empowerment of women through education is the need of the day. This paper reviews various legislative and policy framework to improve the teaching, learning and evaluation aspects in the higher education in India.
\end{abstract}

Keywords: Education, Knowledge, Skills, University, UGC, Empowerment.

\section{INTRODUCTION :}

The word 'education' is derived from the latin word 'Educatum' means 'to bring up' or 'to nourish'. Rig Veda specifies education to be an instrument for self-reliance and selflessness. Kautilya in his 'Arthashasthra' stress education as a training the people to protect the country. Swami Vivekananda said 'Education is known to be manifestation of divine perfection existing within'. Aristotle stated education as the creation of sound mind in a sound body... which develops one's faculty, especially his mind, to experience the power of supreme truth, goodness and beauty to find perfect happiness [1]. Education is one of the most important means of empowering women with the knowledge, skills and selfconfidence necessary to participate fully in the development process by realizing rights and duties [2].

\section{(a) Problems linked to illiteracy}

Empowerment is challenging the power relations by challenging the patriarchal ideology by changing the structure and organizations which works to prevent discriminations by attaining access and control over the material and information resources [3]. Role of integration of women in economic development is always the indicator of economic independence and improved social status [4]. Women suffer from the following disadvantages compared to men. Since from independence, the educational gap between 
women and men is severe with $82.14 \%$ of adult men and $65.46 \%$ of adult women are known to be literates. Women literacy rate is low in rural areas as they are discouraged from higher education including professional or technical literacy. The uneducated women are prone to divorce and desertion, many are living under fear of separation due to unbearable family treatments. Women are the victims of domestic violence committed by husband and his family, due to the negligence about proper right to fight against this evil. In northern India, many girls are married at very young age due to the prevalence of dowry and inability of the parents to educate their girl child due to poverty. The sex discrimination is carried intensively in every segment of social life. Girls are trained for the role of domestics rather than for any occupation. Girls suffer due to the lack of infrastructure worse than boys due to lack of toilets, rest rooms, medical care etc. Lack of transport facilities in rural areas for girls to attend schools and colleges is the main reason for more drop outs after their high school education. Lack of hostels, arrangements especially for the girls belonging to Scheduled Castes and Scheduled Tribe will drastically impact upon their educational status.

The cases of abduction, rape, molestation created a fear in the mind of parents about girl's safety in schools and colleges hence many object giving education to girls. Indian women suffer lot due to forced binding inside the family, without equal share in the parental property, lack of medical care, increased infant mortality rates and less priority to education by reducing their growth and deprive equality from men. The maternal mortality ratio is the number of women's deaths from causes related to pregnancy and childbirth per 1,00,000 live births. The average Maternal Mortality Rate in India is 437 per 1,00,000 live births with (397) in urban and $13 \%$ higher with (448) in rural. Migrant workers are sexually exploited and prone to transmit diseases such as HIV/AIDS, many are addicted to alcoholism, tobacco chewing etc. The World Health Organisation (WHO) detected 14 million persons infected by HIV the number is projected to rise to 30 and 40 million in the near future if effective preventive strategies are not adopted. Due to the decline of fertility rate and mortality rate the number of elderly population among women is increasing. In developed regions one person for every six persons is at the age of 60 years this would reach to one for every four persons by 2025. Women is constrained to be dependent after her marriage. According to 2011 census, 5.6 crore women are belonging to widowed category. Icrease in the life expectancy of women resulted in the raise of widowed population. As life expectancy for women increases, they live as widows for longer period. Among the states Kerala with 6.7\% and Tamil Nadu with 6.4\%, Undivided Andra Pradesh with 5.7 and Karnataka with $5.7 \%$ ratio. The above mentioned social and economic deprivations can be address only through empowering women in every segments of life through education.

\section{(b) Need for Women Education}

Even though women belongs to marginalized majority, they are weak in family decision making and constrained to domestic affairs of cooking, fetching water, rearing children, agriculture, feeding cattle, milking cow etc. The economic condition of the country demand equal participation of women with men in the production process hence, they need to be exposed to outside business. The modern trends pertaining to Free and compulsory education, freedom to hold high offices, political right to franchise and contest in the elections have changed the stereotyped thinking towards women in the society. There is a need for encouraging women education in health care, nutrition, legal education, family welfare, self employment, vocational training suitable to the present requirements. The main aim of educating women is not only for bringing equity in the society but attain economic growth after reducing the poverty. Educating mothers is very important as they nourish, nurture and mould the character of the next generation. The International Women Conference NAROIBI in 1985 discussed upon granting political rights to women.

\section{GENERAL POLICIES FOR WOMEN EDUCATION :}

India recorded a population of 1.31 billion in 2016 among them, 48.1\% (635 million) are women. Indian Government initiated programmes to ensure gender equity and social justice by protecting the interest of women in 
general. Until 1970 it adopted the philosophy of 'Promotion of women's welfare', during 80 's for the 'Development of Women' and after 90's towards 'Empowering women'. It is very essential to create an environment where, every woman can make independent decisions. Indian Constitution grants equality, to all. Education was considered as the weapon to empower women in every walk of life. In order to alter the attitude towards segregation of sexes, series of following legislative and policy framework on education were constituted in India [5].

(1) University Education Commission: It emphasized creating more educational opportunities to women to tackle social prejudice, equal pay for female teachers, separate education for boys and girls upto13 years and co-education after 18 years of age [11].

(2) Secondary Education Commission (1952-53): suggested equal education for men and women in domestic and community issues by constituting four regional colleges of education in Ajmeer, Mysore, Buveneshwar and Bhopal to train multi skilled teachers for schools.

(3) The Central Social Welfare Board (1953): Planning Commission of India constituted to promote schemes for housing for helpless women, Centre for Social Education and Adult Education. Introducing Condensed and Vocational Training Courses in association with voluntary organizations with a annual financial subsidy of Rs 50,000 benefitting 18,000 NGO's under the scheme [12].

(4) University Grants Commission (1956): Constituted under the act of Parliament for promoting and coordinating the University Education, Examination and Research in the Indian Universities. It developed 16 General Development Assistance Programmes for Central, State and Deemed Universities of India. For women welfare it initiated Day Care Centers, Special Scheme for Constructing Women's Hostels, Equal Opportunity Cells, Guidelines for Development of Women's Studies in Universities and Colleges, Research Fellowship for students belonging to Humanities and Social Sciences streams.

(5) National Committee on Women Education (1958-59): The State shall frame
Comprehensive Development Plan for the primary education of Girls with low fee for the low income groups and developing coeducation in middle and secondary education levels.

(6) Condensed Course for Adult Women (1958): The Central Social Welfare Board started 02 years Certification Course for Primary/Middle/Metric students above the age of 15 years with skill development and vocational training to improve employability of rural women along with a stipend of Rs. 60 for residential and Rs. 200 for non residential candidates. Institutions with requisite infrastructure gets grant from the government to conduct middle school or matriculation examination for women between 18-30 years. About 1100 courses were conducted during 1958-1969. It secured the result of $65 \%$ in middle school and $36 \%$ in high schools. Among the successful candidates, $75 \%$ candidates are employed or went for higher education. The estimated budgetary requirement for the scheme under XII Plan was estimated to Rs. 45 crores.

(7) Committee on differentiation of Curriculum for Boys and Girls (1961): Introduced small reforms to eliminate inferiority in women education by adding women relevant topics into the text books and appointing women teachers in Schools.

(8) Correspondence Courses (1962): In Delhi a Directorate of Correspondence courses was opened to make higher education available on distance mode.

(9) Committee to study the Public Support for Women Education (1963): Special attention for women education in the rural areas was given through organizing School Improvement Conferences in the states, preference to local candidates during recruitments to the schools entrusting the task of building infrastructure of schools to the local bodies.

(10) Education Commission (1964-66): after considering the role of women outside to home, the preference was given for separate schools for girls, hostels, scholarships, parttime vocational courses, correspondence courses and employing women teachers. It introduced National pattern of education with $10+2 \& 3$ years consisting 10 years of high school, 02 years of higher secondary \& 3 years 
of graduate education which was later adopted by many states.

(11) Committee on Status of Women (197174): The Committee examines the implications of constitutional, legal and administrative provisions to improve the social status of women. It will assess the impact of women education and employment during the previous two decades. The committee suggested to give consideration to rural masses, frame policy on co-education in primary and secondary schools, introducing general education for both sexes till $10^{\text {th }}$ standard, more relevant courses at university and free education for girls in Secondary level.

(12) Integrated Child Development Services (1975): The Ministry of Women and Child Development (MWCD) conduct Pre-school education (PSE) through the medium of play for social, emotional, cognitive and physical development of the child to prepare him for primary education in formal system under ICDS scheme. The Non-formal education offered as per the Ministry of Human Resource Development (MHRD) to create learning environment to children belonging to 3-6 years.

(13) Assistance to Voluntary Organisation (1982): In order to control atrocities against women financial aid of Rs 81 lakhs was allocated under the IX Five year Plan to the Voluntary Organisations. Women Study Centers in Higher Education for meeting the needs of women, children, aged, infirm, handicapped and other special groups was constituted.

(14) The Ministry of Human Resource Development (MHRD) 1985: The Ministry was constituted by the $174^{\text {th }}$ amendment to the Government of India (Allocation of Business) Rules, 1961. It works with the Department of School Education for universalisation of education and Department of Higher Education to conduct world class opportunities for higher education and research in the country.

(15) Department of Women and Child Development (1985): The Ministry of Human Resources Development constituted a new department for assisting Women and children to develop to their full potentials which prepared National Policy for the Empowerment of Women in 2001.
(16) National Policy on Education (1986): To neutralize the distortions against women, preference is given to women in the National Education System to empower them. It aimed faster development of curricula, textbooks, training, orientation of teachers, involvement of decision makers and educational institutions. All students irrespective of caste, creed, language or sex will get access to quality education to remove disparities and attending to the needs of educationally backward people for gender equity. Encourage admission and retention of girl child in formal and informal schooling. Ensure women participation in educational process, organizing nationwide gender sensitization programmes and parental awareness to create positive climate for girls education. Strengthening open school system at secondary level with own curriculum and examination for certification. Providing quality education in Madrasas after linking it with National Institute of Open Schooling (NIOS) for accreditation. Children studying in the Madrasas will get certification for class 5,8,10 and 12. The scheme of Area Intensive Development was launched in the IX Plan. The scheme for infrastructure development in private aided and unaided minority institutions was introduced in XI Plan. The number of colleges was raised to 824 in 1992 from the prevailing 146 colleges during 1958-59. University at Puna, Padmavathi University at Tirupathi, Womens University Bijapur were constituted [13].

(17) National Literacy Mission (1988): Government of India constituted National Literacy Mission to improve content and process of teaching and learning on a continuous basis. Enrolment of learners and attainment of certain pre determined norms of literacy, numeracy, functionality and awareness was focused. Rural participation at village level was sought by constituting village education committee consisting village pradhan, school teachers, women representatives of SCs and STs and other development functionaries. Adult Education for literacy, basic education and skill development. By the end of $\mathrm{X}^{\text {th }}$ Plan nearly 127.45 million persons got literacy among them $60 \%$ were females, $23 \%$ belonging to Scheduled Castes (SCs) and $12 \%$ to 
Scheduled Tribes (STs). Around 597 districts were covered under Total Literacy Campaigns among which 502 reached Post Literacy stage and 328 reached Continuing Education stage [14].

(18) Mahila Samakhya Programme (1988): It aimed to buildself-esteem, confidence, positive image in the society, critical thinking, decision making among women. They shall get autonomy in choosing the education, employment, reproduction, participate, economic independence through developing skills and knowledge. Legal education shall be provided to encourage their participation in all levels [6].

(19) Joint Council for Vocational Education (JCVE 1990): It monitors the vocational training courses and modules by forming policies and coordinating in the National level to increase mobility in self employment for the poor.

(20) Programme of Action (1992): Scheme to support voluntary agencies for Adult Education and Skill Development for persons between15-35 years. Voluntary sector, Department of School Education and The Ministry of Human Resource Development works collectively in this venture. The Jan Shikshan Sansthan (JSS) established to impart vocational training to those who do not have elementary education. It assists voluntary agencies to encourage continuing education. It tries to achieve self reliance in literacy, numeracy, awareness on deprivation of education, skill development, environmental protection, equality and observance of small family norms [7].

(21) Teachers Education (1995): National Council for Teachers Education a statutory body was constituted under National Council for Teacher Education Act, 1993 on the 17th August,1995. It notified revised Regulations 2014 for 15 programmes on November, 28, 2014. Justice Verma Commission (JVC) appointed by the Government upon the guidance of Hon'ble Supreme Court suggested to recognize 4 year B.A, B.Sc. \& B.Ed programmes, 3 year B.Ed. (Part-time), and 3year B.Ed. \& M.Ed. programme. It increased the duration of B.Ed., B.P.Ed., M.Ed. to 02 years with best international standards with theory, practicum, internship, $25 \%$ school based activities and internship. Information
Communication and Technology, Yoga Education, Gender and Disability/Inclusive Education made as the integral part the curriculum[18]. Open and Distance Learning (ODL) with quality assurance mechanisms and Teacher education institution should get compulsory accreditation in every 5 years from NCTE as per the MoU signed with the NAAC [8].

(22) The National Plan of action for the Girl Child (1991-2000): An action plan by the Government of India for protecting and promoting Girl Child through preventing female foeticide, infanticide, discrimination, assault and abuse. It initiated measures for pure drinking water, strengthening the primary health care, infrastructure, immunization, Polio eradication, supply of drugs, training doctors and para-medical workers, awareness about safe motherhood, primary education in unreserved areas, child care services and community involvement [19].

(23) Sarva Shiksha Abhiyan (2000-2001): Universal education in elementary education is focused to eliminate gender and social gap. It focused on opening new schools, alternative schooling facilities, construction of additional classrooms, toilets, drinking water facility, appointing teachers, periodic teachers training, academic resource support and support for learning. The Right to Education Act gave equal opportunity to the disadvantaged sections of the society including SCs, STs, Muslim Minority, Landless agricultural workers and children with special needs. The pace of girls with boys in education was maintained. It tried to establish teacher centric system with inclusive environment for education of the girls belonging to the oppressed and marginalized sections. It imposed moral obligation of providing primary education upon the parents, teachers, educational administrators and other stakeholders [20].

(24) Kasturba Gandhi Balika Vidyalaya (2004): A scheme of Government of India for establishing residential schools for girls belonging to SC, ST, OBC and Minorities to study upper primary in the Educationally Backward Blocks (EBBs). This scheme was merged with Sarva Shikshan Abhiyan from

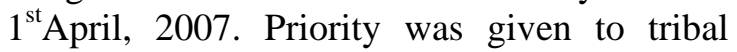
community, areas with low female literacy rate 
and small and scattered habitants who are illiterates. The National Resource Group (NRG) formed under the Mahila Samakhya Programme at National Level shall provide advice to the Government of India on policy matters relating to education of girls. It encourage coordination between research and training institutes, women's movements, educationalists, Non Governmental Institutions for educating girls.

(25) National Curriculum Framework 2005: National Council of Educational Research and Training (NCERT) construed three previous National Curriculum Frameworks during 1975, 1988 and in the year 2000 before initiating this framework. It ensured standard curriculum irrespective of caste, creed, religion and sex. Framework includes the issues regarding making syllabi, textbooks, teaching practices in the school education in India. It suggests to make learning a joyful experience by reducing stress among children. It directed major changes in the design of existing syllabus. Education should inculcate self reliance, dignity, relationship, sense of non violence and unity among the students. It insisted to adopt child centric approach in education to encourage universal enrollment and retention until 14 years. Three language formula to teach regional or mother tongue, Hindi and English should be used. Schools shall impart Mathematics, Computer education, Social Science, Art, Health and Physical education. The children should learn patience, endurance, concentration, cooperation, team work, discipline, and positive attitude. Education through work was made an integral component of school curriculum. Teacher plays the role of a facilitator with continuous appraisal of the students [21].

(26) Model School Scheme (November 2008): Central Board of Secondary Education (CBSE) constituted 6000 model schools with the ratio of one school per block to provide quality education to talented rural children. During 2009-10, 3500 model schools were started by the State Government in the Educationally Backward Blocks (EBB). During 2012-13, 2500 model schools were started under the Public Private Partnership (PPP) for other blocks. The model schools will possess infrastructure and facilities at par with the Kendriya Vidyalaya for the physical, emotional, aesthetic development of students along with academics. The infrastructure should facilitate teaching, sports and co curricular activities along with adequate usage of information and communication technology. Schools shall maintain Teacher pupil ratio at 1:25. Separate classrooms for every 30 students with 1:40 ratio and with teachers for arts and music and counselor. The curriculum should aim to develop leadership, team spirit, participation, soft skills and ability to deal with real life situations. Special emphasize shall be given to health education, health checkups, special teachers for special children, educational tours and NCC training to the students [15].

(27) Incentives to Girls for Secondary Education (May 2008): Centrally sponsored scheme to cover girls between 14-18 years belonging to SC/ST category who have passed VIII standard. The age of Girls should be below 16 years on joining class IX. Married girls, girls studying in private un-aided schools and schools run by Central Government are excluded under the scheme. A sum of Rs. 3000/- is deposited in the name of eligible girls as fixed deposit. The girls are entitled to withdraw the sum along with interest thereon on reaching 18 years of age after passing $10^{\text {th }}$ class examination.

(28) National Means cum Merit Scholarship Scheme (May 2008): Central scheme to award scholarship to meritorious students belonging to economically weaker sections in order to reduce the dropout rate in the VIII standard to encourage them to the study the secondary stage. Selected students will get scholarship of Rs 6000/- per annum to study classes IX to XII in Government, Government Aided and Local Body Schools to those whose parents income limit from all sources are less than Rs. 1,50,000. Since 2013, State Government will conduct separate examination for allotting scholarships. Scholarships are disbursed through the State Bank of India directly into the accounts of the students on quarterly basis[16].

(29) Saakshar Bharat (September 2009): Under the XI Plan, Government of India introduced a scheme to assist voluntary agencies for adult education and skill development. Government announced to 
celebrate International Literacy Day on $8^{\text {th }}$ September. It aimed to raise literacy rate to 80 $\%$ and to reduce gender gap to $10 \%$ by limiting the regional and social disparities of women belonging to SCs, STs and Minorities. All districts with female literacy rate below 50 $\%$ as per census 2001 are covered to raise the instrumental value of female literacy. Intrinsic value of Indian women can be raised by building critical consciousness to take charge of her environment to face deprivations and disabilities[22].

(30) Right to Education (April 2010): The Constitution (Eighty-sixth Amendment) Act, 2002 inserted Article 21-A into the Constitution to provide free and compulsory education for all children between 6 to 14 years as a Fundamental Right. The Right of Children to Free and Compulsory Education (RTE) Act, 2009 came into effect from $1^{\text {st }}$ April, 2010. 'Free education' denotes that no child is liable to pay any fee or charges which prevent him from pursuing and completing elementary education. 'Compulsory Education' imposes obligation upon the government, local authorities and parents to provide admission and ensure attendance of every child between the ages of 6-14 years. The act prescribes norms and standards for the Pupil Teacher Ratios (PTRs), building and infrastructure, working days for the schools, Teacher working hours etc. It requires rational deployment of trained teachers prohibiting physical punishment, harassment during admission, capitation fee, private tuition by teachers and schools without recognition.

(31) Beti Bachao Beti Padhao (2016): Census Report, 2011 states that female child sex ratio who are between 0-6 years has decreased from 976 (1976) to 918 (2011) indicating disempowerment. It reflects pre birth discrimination in the form of sex selection and post birth discrimination against girls. The Government of India introduced this programme in 100 gender critical districts for preventing sex selection and education of girls. It aimed to organize Mass Communication Campaign interlinking National, State and District level by involving different stake holders. The actions under the scheme are lead by the District collectors. Ministry of Women and Child Development undertakes registration of pregnancies in first trimester in
Anganwadi Centres, training the stakeholders, community mobilization and sensitization, announcing gender champions, rewarding the institutions and frontline workers. Ministry of health and Family Welfare monitors the implementation of Pre-Conception and PreNatal Diagnostic Techniques Act, 1994, by encouraging institutional deliveries, registration of birth and strengthening PNDT Cells. Ministry of Human Resource Development encourage enrolment of girls by reducing the dropouts, girl friendly standard to schools, strict implementation of right to education and construction of functional toilets for girls.

\section{MINORITY CENTRIC WOMEN EDUCATION POLICIES :}

(1) National Institute of open Schooling (November 1989): The Ministry of Human Resource Development (MHRD), Government of India started National Open Schooling (NOS) after merging the pilot project of Central Board of Secondary Education to meet the needs of heterogeneous learners till predegree. In July 2002, it was named as The National Institute of Open Schooling (NIOS) with a mission to provide opportunity for continuing education at schools till pre-degree with open learning system in alternative to the formal system for universalisation of education, equity and justice. It offers basic education, secondary education, senior secondary Education, vocational education and life enrichment programmes.

(i) Open Basic Education: It is a distance or continuing educational programme. Separate programmes are offered for children and adults at three levels. OBE level $\mathrm{A}$ is equivalent to class I-III, leval B is equivalent to Class IV-V, and level $\mathrm{C}$, is equivalent to class VI-VIII. NIOS entered into partnership with the study centres of 341 agencies and provides model curricula, study materials, joint certification, orientation of resource persons, Zila Saksharta Samities etc. It allows continuation of learner from Board of School Education and State Open Schools with flexible choice of subjects, courses, pace of learning and transfer of credits from CBSE at secondary and senior secondary levels along with 9 chances to appear in public examinations within 5 years. All the gained credits are accumulated till the 
completion of the required credits. The learner can utilize self instructional materials, audio and video programmes, personal contact programmes, tutor marked assignments, half yearly magazine and On Demand Examination System (ODES) for secondary and senior secondary stages. It offers 26 subjects in Hindi, English, Urdu, Marati, Telgu, Gujrati and Malayalam mediums for Secondary Examinations and 19 Subjects in Hindi, English and Urdu mediums for Senior Secondary Examinations.

Table 01: Courses offered by The National Institute of Open Schooling (NIOS)

\begin{tabular}{|c|c|c|c|}
\hline $\begin{array}{l}\text { Sl. } \\
\text { No }\end{array}$ & Title of the Course & Duration & $\begin{array}{c}\text { Entry } \\
\text { Qualification }\end{array}$ \\
\hline 01 & Secretarial Practice & One Year & $\begin{array}{l}\text { Senior } \\
\text { Secondary }\end{array}$ \\
\hline 02 & $\begin{array}{l}\text { Certificate in Rural Health for Women (Gram Sakhi) } \\
\text { 1. Basics of Health Care } \\
\text { 2. Health and Environment } \\
\text { 3. Health Education } \\
\text { 4. Health Extension Activities }\end{array}$ & One Year & IV class pass \\
\hline 03 & $\begin{array}{l}\text { Advanced Certificate in Rural Health for Women } \\
\text { 1. Communication skills in Health Education } \\
\text { 2. Medical, Clinical and Diagnostic Skills } \\
\text { 3. Health Management } \\
\text { 4. Emerging issues in Health Care. }\end{array}$ & One Year & $\begin{array}{l}\text { Passouts of } \\
\text { Certificate in } \\
\text { Rural Health } \\
\text { for Women. }\end{array}$ \\
\hline 04 & $\begin{array}{l}\text { Certificate in Care of Elderly } \\
\text { 1. Basic Life Sciences } \\
\text { 2. Aspects of Aging } \\
\text { 3. General care and specific needs of Elderly } \\
\end{array}$ & One Year & $\begin{array}{l}\text { Senior } \\
\text { Secondary }\end{array}$ \\
\hline 05 & $\begin{array}{l}\text { Certificate in Computer Applications } \\
\text { 1. Basic Computing Skills } \\
\text { 2. Computer Applications }\end{array}$ & One Year & $\begin{array}{l}\text { Senior } \\
\text { Secondary }\end{array}$ \\
\hline 06 & $\begin{array}{l}\text { Diploma Basic Rural Technology } \\
\text { 1. Home and Health } \\
\text { 2. Agriculture } \\
\text { 3. Material, Mechanics, Energy and Environment }\end{array}$ & One Year & Not Prescribed \\
\hline 07 & Certificate in Yoga & Six months & Secondary \\
\hline 08 & Jan Swasthya & One Year & $\begin{array}{l}\text { Senior } \\
\text { Secondary }\end{array}$ \\
\hline 09 & Cutting and Tailoring & Six Months & Not Prescribed \\
\hline 10 & Dress Making & Six Months & $\begin{array}{l}\text { Below } \\
\text { Secondary }\end{array}$ \\
\hline 11 & Poultry Farming & One Year & $\begin{array}{l}\text { Senior } \\
\text { Secondary }\end{array}$ \\
\hline 12 & Play Center Management & One Year & $\begin{array}{l}\text { Senior } \\
\text { Secondary }\end{array}$ \\
\hline 13 & Paripurna Mahila & One Year & Secondary \\
\hline
\end{tabular}

(2) National Commission for Minorities Educational Institutions (NCMEI 2004): (ii) Vocational Education and Training (VET): The Government initiated centrally sponsored School-based vocational education in 1988 as an alternative to the higher education. It aimed to meet the need for skilled and middle level manpower for the growing organized and unorganized sectors in the economy. These courses (Refer Table 01) are expanded over the years based on the needs of learners and market demands for both urban and rural sectors. 
India constituted it with head quarters in Delhi. This genesis can be traced to the UPA government manifesto for 'National Common Minimum Programme'. The parliament enacted The National Commission for Minority Educational Institutions Act 2004 later amended under NCMEI(Amendment Act 2006). Article 30 Indian constitution states that "all minorities, based on religion or language have the right to establish and administer educational institution of their choice”. The commission being a quasi judicial body entrusted with the powers of civil court with the powers to adjudicate, advice and recommend any suggestions. The Commission is headed by a Chairman who shall be the judge of Delhi High Court and two members nominated by Central Government. It provided a forum for the minority educational institutions to file their grievances to get speedy relief. It investigate matters connected grant of No Objection Certificate (NOC) by the state government, granting minority status, opening new schools, colleges and additional courses, grants in aid, financial assistance, appointment of teachers, pay scales, teaching aids and facilities. By treating Minority Educational Institutions on par with government institutions seek into the non availability of Urdu books, Urdu teachers, inadequate payment to Madrasa employees, grants and retirement benefit to madarasa staffs and extension of Sarva Shikshana Abhiyan to Minority Educational Institutions of rural areas.

(3) Nai Roshni The Scheme for Leadership Development of Minority Women (201213): Ministry of Minority Affairs started this scheme to benefit Muslim, Sikh, Christian, Buddhist and Parsi women notified under section 2 (c) of the National Commission for Minorities Act, 1992. The scheme permitted a representative mix of women from SCs/STs/OBCs, disabled and Non-minority communities not exceeding $25 \%$ of a project. The trainees shall be selected among the Elected Women Representatives (EWRs) from the communities under Panchayat Raj system. The scheme aims to empower women, with knowledge, tools and techniques to interact with government systems, banks and other institutions. It conducts Non-residential Training in the Village/Urban Locality for 25 women in each batch by using existing facilities or rented permanent structure for six hours per day for six days avoiding festive occasions along with training materials in local languages, meal, crèche facility for their children and Stipend credited to the bank accounts of the trainees to compensate wage loss and Residential Leadership Development Training along with boarding/lodging for 25 selected women along with training fees, training materials, boarding, food, refreshment, travel expenses and stipend credited to their bank accounts for the duration of the training period.

(4) Maulana Azad National Fellowship for Minority Students: Integrated five years fellowship in the form of financial assistance to 756 students from minority communities with 30 per cent reservation to minority women every year notified by the Central Government to pursue M.Phil and Ph.D courses. The fellowship will cover all the universities recognized by the University Grants Commission under section 2(f) and section 3 of the UGC Act implemented by the Ministry of Minority Affairs. The unclaimed fellowships will be carried forward to the next academic year. The fellowship for M.Phil for 2 years and for integrated M. Phil and Ph.D courses for 2 years with the admissibility of JRF and SRF for the remaining 3 years with a preference to the candidates who conducts research pertaining to linguistic minorities. In case of more candidates the UGC selects candidates considering the percentage of marks obtained in the Post Graduation examination. The scholarship shall be awarded to branches in the order of Arts, Commerce, Science and Engineering respectively.

(i) Quantum of Fellowship: The candidate should have registered for regular and full time M.Phil/Ph.D Course in any university by fulfilling conditions of admission of that university, the minority students once considered eligible for the fellowship shall not be entitled to benefits under any other source, central or state government or bodies like UGC for the same study, Prior clearance of NET/SLET examination will not be a prerequisite for award of this scholarship. In order to qualify for the award of JRF/SRF the UGC norms would be applicable at pre-M.Phil and Pre-Ph.D stage, respectively, including the 
minimum score of $50 \%$ at the Post Graduate Level. UGC will select the candidates for award of this scholarship in a transparent manner. UGC shall disburse the fellowship amount to the candidates through electronic clearance system (ECS) wherever feasible. The decision of UGC in regard to awarding is final and no appeal would lie against any decision except provided under the law in force. The income ceiling of the parents/guardians of the candidate for this scholarship will be Rs.2.5 Lakh per annum. The quantum of fellowship for JRF and SRF will be at par with the UGC fellowship as amended from time to time. Escort or Reader Assistance at Rs. 2,000 per month in case of physically and visually challenged candidates (Refer Table 02 and 03)

Table 02: JRF/ SRF Rates per candidate for Arts and Commerce Branches

\begin{tabular}{|l|l|l|l|l|}
\hline \multicolumn{1}{|c|}{ Year } & \multicolumn{1}{|c|}{$\begin{array}{c}\text { Fellowship Per } \\
\text { Month }\end{array}$} & \multicolumn{1}{|c|}{$\begin{array}{c}\text { Contingency } \\
\text { per Annum }\end{array}$} & $\begin{array}{c}\text { Total } \\
\text { Assistance per } \\
\text { Annum }\end{array}$ & \multicolumn{1}{|c|}{} \\
\hline 01 (JRF) & $\begin{array}{l}\text { Rs. } 12,000 \times 12= \\
\text { Rs. } 1,44,000\end{array}$ & Rs. 10,000 & Rs. 3000 & Rs. $1,57,000$ \\
\hline 02 (JRF) & $\begin{array}{l}\text { Rs. } 12,000 \times 12= \\
\text { Rs. } 1,44,000\end{array}$ & Rs. 10,000 & Rs. 3000 & Rs. $1,57,000$ \\
\hline $03($ SRF) & $\begin{array}{l}\text { Rs. } 14,000 \times 12= \\
\text { Rs. } 1,68,000\end{array}$ & Rs. 20,500 & Rs. 3000 & Rs. $1,91,500$ \\
\hline 04(SRF) & $\begin{array}{l}\text { Rs. } 14,000 \times 12= \\
\text { Rs. } 1,68,000\end{array}$ & Rs. 20,500 & Rs. 3000 & Rs. $1,91,500$ \\
\hline 05(SRF) & $\begin{array}{l}\text { Rs. } 14,000 \times 12= \\
\text { Rs. } 1,68,000\end{array}$ & Rs. 20,500 & Rs. 3000 & Rs. $1,91,500$ \\
\hline Total & Rs. $7,92,000$ & Rs. 81,500 & Rs. 15,000 & Rs. 8,88,500 \\
\hline
\end{tabular}

Source: Ministry of Minority Affairs, Government of India, 2016.

Table 03: JRF/ SRF Rates per candidate for Science and Engineering Branches

\begin{tabular}{|c|c|c|c|c|}
\hline Year & $\begin{array}{c}\text { Fellowship Per } \\
\text { Month }\end{array}$ & $\begin{array}{l}\text { Contingency } \\
\text { per Annum }\end{array}$ & $\begin{array}{c}\text { Departmental } \\
\text { Assistance per } \\
\text { Annum }\end{array}$ & Total \\
\hline 01(JRF) & $\begin{array}{l}\text { Rs. } 12,000 \times 12= \\
\text { Rs. } 1,44,000\end{array}$ & Rs. 12,000 & Rs. 3000 & Rs. $1,59,000$ \\
\hline 02(JRF) & $\begin{array}{l}\text { Rs. } 12,000 \times 12= \\
\text { Rs. } 1,44,000\end{array}$ & Rs. 12,000 & Rs. 3000 & Rs. $1,59,000$ \\
\hline 03(SRF) & $\begin{array}{l}\text { Rs. } 14,000 \times 12= \\
\text { Rs. } 1,68,000\end{array}$ & Rs. 25,000 & Rs. 3000 & Rs. $1,96,000$ \\
\hline 04(SRF) & $\begin{array}{l}\text { Rs. } 14,000 \times 12= \\
\text { Rs. } 1,68,000\end{array}$ & Rs. 25,000 & Rs. 3000 & Rs. $1,96,000$ \\
\hline 05(SRF) & $\begin{array}{l}\text { Rs. } 14,000 \times 12= \\
\text { Rs. } 1,68,000\end{array}$ & Rs. 25,000 & Rs. 3000 & Rs. $1,96,000$ \\
\hline Total & Rs. 7,92,000 & Rs. 99,000 & Rs. 15,000 & Rs. 9,06,000 \\
\hline
\end{tabular}

Source: Ministry of Minority Affairs, Government of India, 2016.

(5) Maulana Azad National Scholarship Scheme for Meritorious Girl Students of Minority: Maulana Azad Education Foundation registered under the Societies Registration Act, 1860, on $6^{\text {th }}$ July, 1989 is a voluntary Non Profit Social Service Organisation funded by the Ministry of
Minority Affairs, Government of India. National Scholarship Scheme recognize, promote and assist meritorious girl students who cannot continue their education without financial support. The Scholarship is granted to students passed S.S.L.C. exam and taking admission to $11^{\text {th }}$ standard after declaration of 
$10^{\text {th }}$ standard result for that year. Girls belonging to Muslims, Christians, Buddhists, Sikhs and Parsis securing not less than $55 \%$ aggregate marks in the tenth standard with family income from all sources shall be less than Rs. 1 lakh in the preceding financial year are eligible for this benefit. The girl can apply to this scheme only after confirming her admission to Class XI in an institutions recognized by the Government or other competent authority. A student getting a scholarship from any other source would not be eligible for this scholarship, the last date of receiving the application by the foundation is $30^{\text {th }}$ September which must be adhered to and the amount of scholarship will be Rs. 12,000/(Rupees Twelve Thousand Only) which will be released in two installments of Rs. 6000/each. The first installment will be released after sanctioning the scholarship and the second installment released after the student submits proof of passing class $11^{\text {th }}$ and get admission to class $12^{\text {th }}$.

\section{(6) Educational Loan from National} Minorities Development Finance Corporation: The NMDFC extends educational loans to facilitate job oriented education for the eligible persons belonging to Minorities. Maximum amount of Rs. 10 Lakhs is available at the rate Rs. 2 Lakhs per annum for technical and professional courses of durations not exceeding five years and Rs. 3 lakhs is for short duration cost intensive skill development training upto 01 year. Further for courses abroad, a maximum amount of 20 lakhs is available at Rs 4 lakhs per annum for any course with duration of maximum 5 years. Funds for this purpose are made available to the State Channelizing Agencies at an interest of $1 \%$ per annum to lend to the beneficiaries at $3 \%$ interest per annum. The loan shall be payable within five years after completion of the course.

\section{CONCLUSION :}

India by recording Gross Domestic Product (GDP) at 7.5 per cent by the end of 2016 recognized to be one among the fastest growing economies in the world. It has recognized that sustainability in economic growth can be attained only through the equal participation of women in the development process of the country. In recognition to the
'International Year of Women' accepted after 1975, The Government of India formed National Plan of Action for Women 1976 to facilitate women to attain social, political and economic excellence through integrated approach of health and education. The government began to direct its effort towards mainstreaming of women into the national development process by enacting various legislations to install equality, social justice and fraternity in the society [9]. The legislative and policy framework on education has facilitated the spread of education in the country. According to Government of India census survey report, the literacy rate grew from $18.33 \%$ (1951), to $28.30 \%$ (1961), $34.45 \%$ (1971), $43.57 \%$ (1981), $52.21 \%$ (1991), $64.84 \%$ (2001) to $74.04 \%$ during (2011). Overall Literacy rate increased by 9.2 \% from $64.84 \%$ prevailed in 2001 to $74.04 \%$ in 2011. Female literacy rate increased by $10.97 \%$ from $53.67 \%$ prevailed in 2001 to $64.64 \%$ in 2011. Number of illiterates (7+ age group) decreased from 304.10 million prevailed in 2001 to 282.59 million in 2011. Gender disparity in literacy rates declined by $5.34 \%$ points from $21.59 \%$ prevailed in 2001 to $16.25 \%$ in 2011 [10]. Gender equity can be promoted by changing the interaction at home, school, college, university and workplaces by creating favourable environment fostering the equality. The Ministry of Women and Child Development and Ministry of Human Resource Development, Government of India jointly instructed the Universities to implement 'Gender Champions' programme to recognize the leadership among women by the end of 2015. Most of the women are working as doctors, engineers, CAs, Politicians exercising 56 per cent of franchise in the elections. On 19th June, 2016, Avami Chaturvedi, Bhawana Kanth and Mohana Singh cadets of Dundigal Air Force Academy created history by becoming first commissioned female fighter pilots in the country Parents have come out of the orthodox mindset and realized the value of providing education to their daughters. Extensive reforms in judicial mechanisms for responsive, sensitive administration of justice need to be attained. It is also very important to treat the loopholes of the related laws and check the execution procedures in detail. 


\section{REFERENCES :}

[1] Rao, R. K. (2005). Women in Education. Kalpaz Publications, Delhi, 57-69.

[2] Carol Chapnick Mukhopadhyay \& Susan Seymour (1994). Women, Education and Family Structure in India, Westview Press, Boulder, 37-57.

[3] Geetha, B. (2007). Self Help Groups, A Social Movement, Social Welfare, Vol. 54, No 11, Fib-March, 12.

[4] Lalitha, N. (1995). Rural Women Empowerment and Development Banking, Kanishka Publication and distributors, New Delhi, 86-87.

[5] Vijay Kaushik \& Bela Rani Sharma (1998). Indian Women Through Ages, Sarup \& Sons, New Delhi, 235-277.

[6] Shramshakti (1988). Report of the National Commission on Self Employed Women and Women in the Informal Sector, New Delhi, June.

[7] Rao Y. V. \& Francis C (1990). Action Oriented Adult Literacy and Education in WCADL', Journal of Rural Development, Vol. 12, 6, 651-655.

[8] National Council for Teacher Education Act, 1993.

[9] Parvathy Appaiah, Shankar Rao and Jayanthi P. Shenoy, (2015-16). Human Rights, Gender Equity and Environmental Studies, Jai Bharath Prakashana, Mangalore, Tenth Edition, 37-103.

[10] Pradeep M.D. \& Charan Raj (2016). "Recent trends of Socio-Economic Empowerment of Elderly-Interventions towards broad based benefits in India” International Journal of Current Research and Modern Education (IJCRME), Volume I, Issue I, ISSN (Online) 2455-5428, 692-700.

[11] University Education Commission (194849). Government of India, Vol. I, Manager of Publication, New Delhi.

[12] The Central Social Welfare Board (1953). Planning Commission, Government of India.

[13] National Policy on Education (1986) Programme of Action, Ministry of Human Resource Development, New Delhi.

[14] National Literacy Mission (1988), Government of India.

[15] Model School Scheme (November 2008), Central Board of Secondary Education (CBSE), Government of India.

[16] National Means cum Merit Scholarship Scheme (2008), May.

[17] The Right Education (RTE) Act, 2009.

[18] Website maintained by National Council for Teacher Education retrieved on $27^{\text {th }}$ April, 2016 at 12.40 p.m.

[19] The National Plan of action for the Girl Child (1991-2000), Government of India.

[20] Sarva Shiksha Abhiyan (2000-2001), Government of India.

[21] National Curriculum Framework (2005).

[22] Saakshar Bharath Mission, Department of School Education and Literacy, Ministry of Human Resource Development, Government of India. 